DOI: http://dx.doi.org/ 10.24235/al.ibtida.snj.v6i1.3814

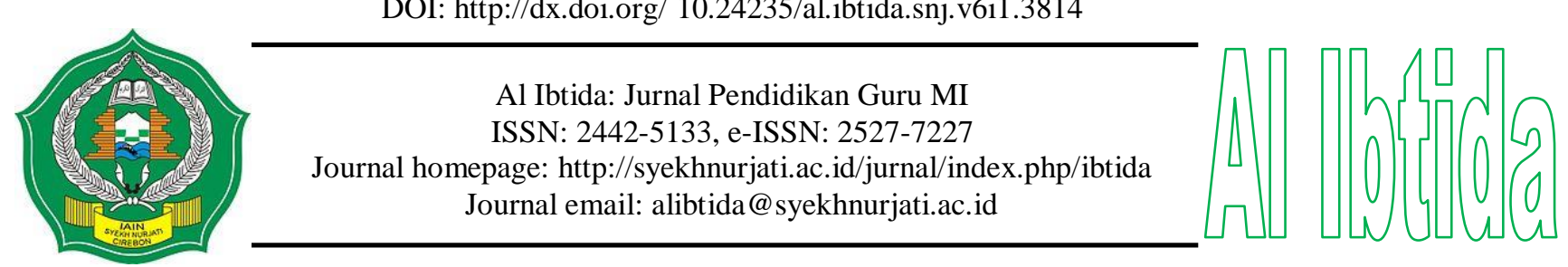

\title{
The Innovation of Gabriel Method in Improving Al-Qur'an Memorization of Islamic Elementary School Students
}

\author{
Kanzul Athiyah* \\ *Islamic Religion Education Study Program, Faculty of Islamic Religion, \\ University of Nurul Jadid \\ Email: kanzulathiyah1@gmail.com \\ Syaiful Islam** \\ ** English Language Education Study Program, Faculty of Social \& Humanities \\ University of Nurul Jadid \\ Email: syaifulislam182@gmail.com
}

Received: January $16^{\text {th }}, 2019$. Accepted: June $14^{\text {th }}, 2019$. Published: June $30^{\text {th }}, 2019$.

\begin{abstract}
Memorizing the Qur'an 30 juz is not an easy thing for SD/MI students who sometimes cannot read the Qur'an smoothly. One method that can be used by students in memorizing the Qur'an is the Gabriel method. This study aims to describe the application of the Gabriel method in improving memorization of Al-Qur'an for SD/MI students at the Al-Hasyimiyah Qur'anic Education Institution of Nurul Jadid Islamic Boarding School Paiton Probolinggo. Data collection techniques used in this study were in-depth interviews and observations. Meanwhile, the research data were analyzed using descriptive analysis. The results of the study show that 1) Al Qur'an learning activities are carried out every night after dawn prayer in congregation and Maghrib prayer in congregation; 2) the highest achievement of memorizing is 1 to 2 letters, while the lowest is 5 to 7 verses; 3 ) the obstacles faced in applying Gabriel method is the low ability of students to recall the Qur'an memorization has been achieved; 4) current teachers are only able to make verse movements only in the letter Al-Mulk, the rest, are in the process of being made. However, the application of the Gabriel method is proven to be able to improve the memorization of the $\mathrm{Al}$ Qur'an of SD/ MI students.
\end{abstract}

Keyword: gabriel's method, memorizing Al-Qur'an, SD/MI students.

\begin{abstract}
Abstrak
Menghafal Al-Qur'an 30 juz bukanlah hal yang mudah bagi peserta didik SD/MI yang kadang belum dapat membaca Al-Quran dengan lancar. Salah satu metode yang dapat digunakan peserta didik dalam menghafal Al Qur'an adalah metode jibril. Penelitian ini bertujuan untuk mendeskripsikan penerapan metode jibril dalam meningkatkan hafalan Al-Qur'an peserta didik MI/SD di Lembaga Pendidikan Qur'an Al-Hasyimiyah Pondok Pesantren Nurul Jadid Paiton Probolinggo. Teknik pengumpulan data yang digunakan dalam penelitian ini adalah wawancara mendalam dan observasi. Sementara itu, data hasil penelitian dianalisis menggunakan analisis
\end{abstract}


deskriptif. Hasil penelitian menunjukkan bahwa 1) Kegiatan pembelajaran al Qur'an dilakukan setiap malam seusai sholat subuh berjamaah dan sholat Maghrib berjamaah; 2) pencapaian hafalan peserta didik paling tinggi adalah 1 surat sampai dengan 2 surat, sedangkan paling rendah adalah 5 sampai 7 ayat; 3) kendala yang dihadapi dalam penerapan metode jibril ini adalah rendahnya kemampuan peserta didik dalam mengingat kembali hafalan Al Qur'an yang telah dicapai; 4) para guru pendamping saat ini hanya mampu membuat gerakan ayat hanya pada surat Al-Mulk saja, selebihnya sedang dalam proses pembuatan. Namun demikian, penerapan metode jibril terbukti mampu meningkatkan hafalan Al Qur'an peserta didik SD/MI.

Kata kunci: metode jibril, hafalan Al-Qur'an, peserta didik SD/MI.

\section{INTRODUCTION}

Education is the interaction between teachers and students in helping to master the goals of education (Kartiani, 2015). In improving the quality of education, teachers become the spearhead for students. Students directly interact with the teacher in the learning activity. Teacher acts to deliver the material for learning or becomes an informant for students. Therefore, it is very important to improve the quality of learning, especially in terms of teacher creativity. Not only in terms of teacher creativity but also in terms of teacher professionalism which is also very necessary. Because the future of students depend on how the teacher teach as a driver in education. The teacher is also expected to be able to recognize who his students are. Recognition of students is important because of their unique (Martani, 2012).

Learning is basically an effort to direct students into the learning process so that they can obtain learning goals as expected (Jannah, 2018). The effectiveness of the learning process can be seen from the learning methods that the teacher uses. In the learning process teacher also involved by participants in using learning methods to specialize the activity and create a good environment (Majid, 2012). Teaching methods can be interpreted as a way to connect educators and students in the teaching and learning process. It can be said that the method implies the objectives planned in a planned and systematic work sequence. The effectiveness of method as a means of achieving learning objectives depends on the good method used (Mundiri \& Zahra, 2017). Therefore the method is the most important component to regulate the running of a learning. So, the teacher who will carry out the learning process must prepare the method first and its aim. It can be said that the learning runseffectively, not saturating and not in vain. Thus the learning method is a tool for creating good teaching and learning activities.

The Qur'an is the masdar word form of Qa-ra-a yaq-rau Qur'an (Drajat, 2017). Al quran is a revelation revealed to the Prophet Muhammad. Mutawatir (gradually) through the Gabriel for guiding humans to remain in the straight path, namely Islam. Studying, understanding, and practicing the Qur'an in aspects of daily life is mandatory for every Muslim (Herdiansyah \& Afrianto, 2013). The Qur'an is a holy book that is preserved authenticity. Allah S.W.T has 
guaranteed its preservation, and does not impose it on anyone. Unlike other holy books, which are only maintained by the people who receive them (Al Maududi, Mujahidin, \& Hafidhuddin, 2014).

In Islam, the command to read the Qur'an is the responsibility of all Muslims (Ramli \& Hamzah, 2017). The purpose of reading Qur'an for children is none other than the preparation of them to be a Qur'anic Muslims generation, namely the generation who love and reading the Qur'an, and place it as their daily views (Sa'diah, 2013). By getting children accustomed to recognizing and reading the Qur'an at an early age, then they have grown up, they will feel bored when they leave Al-Qur'an even if only within a day. Luckily someone when they are close to the Qur'an. It is full of blessings, besides reading it gets peace of mind, studying the Qur'an is not even just learning about vocabulary, and the selection of editors only, but the contents are expressed, implied even to on the impression contained therein. The Qur'an is like a gem that emits light that varies according to each viewpoint.

Some of the activity in studying Al Quran, Muslims learn, recite correctly according to tajwid, interpret, and memorize the Quran (Akbar, 2013). People who keep the Qur'an by memorizing, understanding, even practicing the contents include lucky people. People who memorize the Quran are fortunate, and their parents will be blessed with a crown that shines brighter than the sun.

Memorizing 30 juz ofAl-Qur'an is not an easy, especially for students at the elementary / MI level. Sometimes they cannot read the Quran smoothly. Atabik (2014) mentions in his research entitled The living Qur'an: Potret Budaya Tahfidz Al-Qur'an di Nusantara that it takes around 2 to 4 years to complete memorizing 30 juz in Islamic boarding schools. Including a very long time to memorize the Qur'an. Therefore, various methods emerged to accelerate the memorization of the Qur'an.

According to Ansari (2017) in his research entitled Pelaksanaan karantina tahfidz selama 30 hari untuk usia SD/MI di kota Banjarmasin, it was stated that memorizing the Qur'an can be done within a period of 1 month. The program provides an opportunity for Elementary School/ Islamic Elementary School Muslims who are interested in participating in memorizing Al-Qur'an activities without having to enter Islamic boarding schools. Especially for those who are still in school, because they are held during long holidays. This activity is held twice a year. Whereas according to Ansari \& Barsihanor (2018) in his research entitled Sistem Karantina Tahfidzh 1 Hari untuk Anak Usia SD/MI Sistem Karantina Tahfidzh 1 Hari untuk Anak Usia SD/MI 1 mentioned that memorizing Al-Quran can be done every day at Al-Haramain house of Tahfidzh. Tahfidzh quarantine for one day can be an alternative to increase and accelerate their memorization quantity. 
In order to speed up the memorization process, educators need to apply methods that can facilitate students to memorize the Qur'an. In this sophisticated era, several methods have been found. It can be used to memorize the Qur'an become easier. Abdulrab Nawabuddin argues that the etomological meaning of memorizing Qur'an is different from memorizing the others. This difference is due to two reasons. First, memorizing the Qur'an is memorized perfectly throughout it, so that people who memorize half or a third of the Qur'an have not been said to be haafidz (people who memorize the Qur'an). secondly, memorizing the Qur'an must be continuous and always keep the memorized so as not to forget. Abdulrab was very careful in giving the title Haafidz. because, a Hafidz and Haafidzah, must fulfill several conditions, namely:

1. A hafidz must memorize the Qur'an as a whole (30 juz) so that someone is not said to be a hafidz if only memorized a part, or one third.

2. Someone is said to be hafidz if he can keep his memorization from forgetfulness (Fachrudin, 2017).

One method of memorizing Al-Qur'an that has been widely used is the Gabriel method. Gabriel method began when the Prophet Muhammad received the first revelation from Allah SWT through the angel Gabriel. which at that time the angel Gabriel read the first verse that came down to the Prophet Muhammad and asked to imitate the verse that the angel Gabriel read. Even though the Prophet could not imitate, the angel Gabriel still forced the Prophet to imitate it to be repeated three times. At the time of the Prophet and the Companions of the Gabriel method had already been used. The friends imitated and memorized outside the head of each revelation in the form of the verses of the Qur'an which were read by the Prophet Muhammad (Imtihana, 2016).

The first originator of the Gabriel method was the Qur'anic Education institution at Singosari Malang under the guidance of KH.M. Bashori Alwi. As the originator of Gabriel method, KH. M. Bashori Alwi said that the fundamental technique of Gabriel method starts from reading one verse or waqaf, and then imitated by all students. The teacher reads one to two times that are imitated by all students, until the teacher continues the verse then and imitated by all students, and so on until the reading of students is exactly the same as the teacher (Khozim, 2010).

Some other memorizing institutions of the Qur'an have also applied the Gabriel method as the memorization method. One of the memorizing institutions of Al-Qur'an that has implemented the Gabriel method is the Education Institute of Qur'aan Al-Hasyimiyah Nurul Jadid Islamic Boarding School Paiton Probolinggo. The coach of Tahfidz at Al-Hashimiyah stated that Gabriel method is the talqin-taqlid method which means imitating. Gabriel method place the teacher to provide reading examples to students. The teacher reads the verse slowly, 
then the students imitate the reading,and so on. Gabriel method is a teacher center method, because of the dominant role of the teacher in teaching and learning process. This activity must be carried out continuously so that the memorization owned is not easily forgotten. This study aims to describe the application of Gabriel method in improving memorization of Al-Qur'an for Islamic elementary students at the Al-Hasyimiyah Qur'anic Education Institution of Nurul Jadid Islamic Boarding School Paiton Probolinggo.

\section{METHODS}

This study uses qualitative descriptive research, where place the researcher as the main instrument. In qualitative research, humans are the main research instrument and there is no other choice. The researcher is the only tool that can achieve everything. All the needsdevelope in a situation that is completely uncertain and unclear throughout the study. The research was conducted at Al-Hasyimiyah Qur'anic Education Institution Nurul Jadid Islamic Boarding School Paiton Probolinggo.

The instrument of this study was through two stages, namely interviews and observations. Interviews were conducted to find out somethings that happened in memorizing Al-Qur'an by applying the Gabriel method. In addition, the researchers also wanted to know how many elementary school/ Islamic elementary school students resided in the institution, and what the achievement targets must be achieved by the students. In addition to interviews, researchers also conducted observations to prove the results of interviews.in order to avoid confusion between interviews with coaches and some students. From these observations, researchers canfind out how their daily lives. The subject of the study was the coach of Tahfidz / teacher and students of the elementary school/ Islamic elementary school level in Al-Hasyimiyah Qur'anic Educational Institution, Nurul Jadid Islamic Boarding School.

\section{RESULTS AND DISCUSSION}

\section{Innovation of the Gabriel method in increasing memorization of the Qur'an}

Al-Hasyimiyah Qur'anic Educational Institution Nurul Jadid Islamic Boarding School Paiton Probolinggo is one of the institutions that implement Al-Qur'an learning, especially in terms of memorization. There are 2 programs that are concentrated in this institution. Among them are Tahfidzul Qur'an and Tahsinul Qiro'ah. Tahfidzul Qur'an consists of students that has finished their memorizing on juz 30 and juz 1 and has an ability to continue memorizing. And for Tahsinul Qiro'ah consists of students who are still taking the reading and song reinforcement. Students who want to enter the Qur'an Education Institution on Tahfidz program usually have to fulfill certain conditions, one of which is to have memorized juz 30.

Based on the results of research conducted at Al-Hasyimiyah Qur'anic Educational 
Institution Nurul Jadid Islamic Boarding School Paiton Probolinggo founded that: 1) Teaching and learning activities are carried out every time after dawn prayer in congregation and Maghrib prayer in congregation. The deposit session was held in the morning at 05.30 WIB. until 06:00 WIB. While the murojaah session (Repeating memorization) was held in the night at 18:00 WIB until 18:30 WIB. 2) The highest achievement of memorizing students is 1 to 2 letters, while the lowest is 5 to 7 verses and their movements. 3) the obstacles faced in learning Gabriel's method is the low memory to recall the memorization that has been achieved. 4) current coaches are only able to make verse movements only in the surah Al-Mulk, the others are in the process of being made. Because at this time, the coach does not only focus on one point, namely guiding the students, but the supervisors for the special age of elementary school / Islamic elementary school are also undergoing their studies, at one of the universities in Probolinggo.

In addition, there is no need for grouping the students in learning because there are only 5 students of elementary / MI level who use the Gabriel method. Thus it is easier for educators or coaches to carry out the learning process effectively. It is also an advantage for students, because their free time after making a deposit, they can continue their respective activities. So the way in which educators do is to recite one verse as the following example by moving words per word, then one by one they sequentially mimic verses with movements. The first target for students to memorize is Surah An-Naba. In implementing this method the coach of Tahfidz Al-Hasyimiyah guides the students of elementary school / MI level through several processes that it: the first, reading Surah Fatihah. Before starting the lesson, the teacher conducts Tawassul (the NU Tradition by mentioning the ruhthat had already died first) which is devoted to the Messenger of Allah, the Ulama ', and does not forget the founders and caregivers of the Nurul Jadid Islamic Boarding School. Surah Fatihah also give to the Hafidz, in oreder to make it easy for memorizing and not easily forget the memorization that has been obtained (Interview with Ustadzah Faiq: December 19, 2018).

Second, reading Asma'ul Husna with songs. Reading Asma'ul Husna with songs will not make students bored, especially in a hurry to move from Majlis Ta'lim.Because the song used is very beautiful. The movements made by the coach are adjusted to the meaning. (interview with Ustadzah Faiq: December 19, 2018). Third, the teacher asks to read a verse that has been memorized in the previous meeting and movement. Fourth, the teacher continues the verse. In the practice of moving the hand and part of the body in accordance with the sentence read. And according to the meaning that exists. The example of the verse is QS. Al Mulk (1-5). 


$$
\text { بِسنمِ اللَّه الرَّحْمنِ الرَّحِيْم }
$$

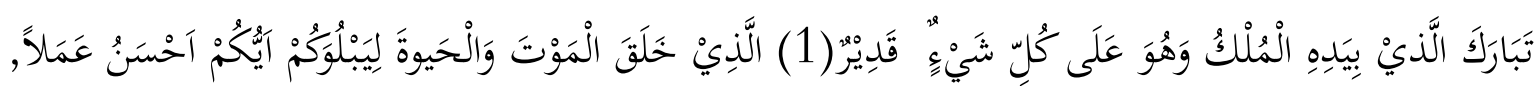

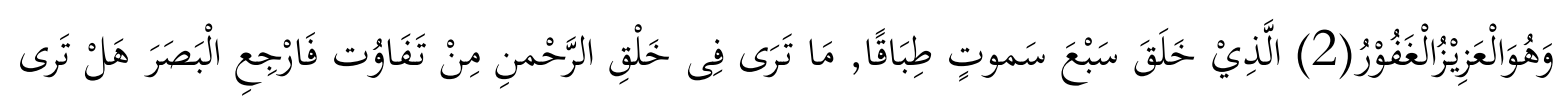

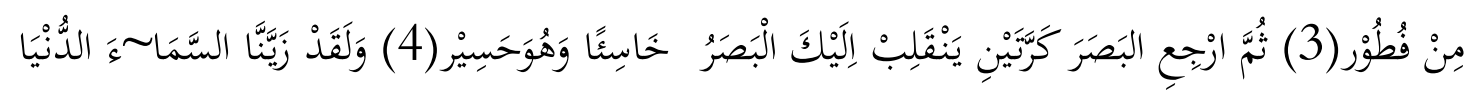

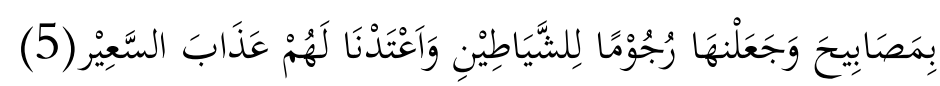

The following is an illustration of the recitation of Surah Al-Mulk and its movements
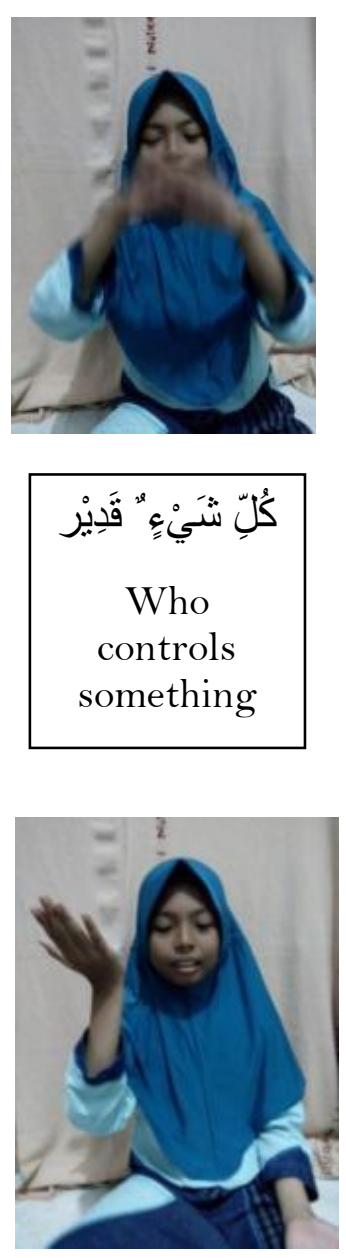

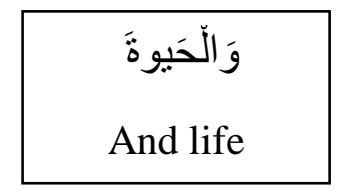
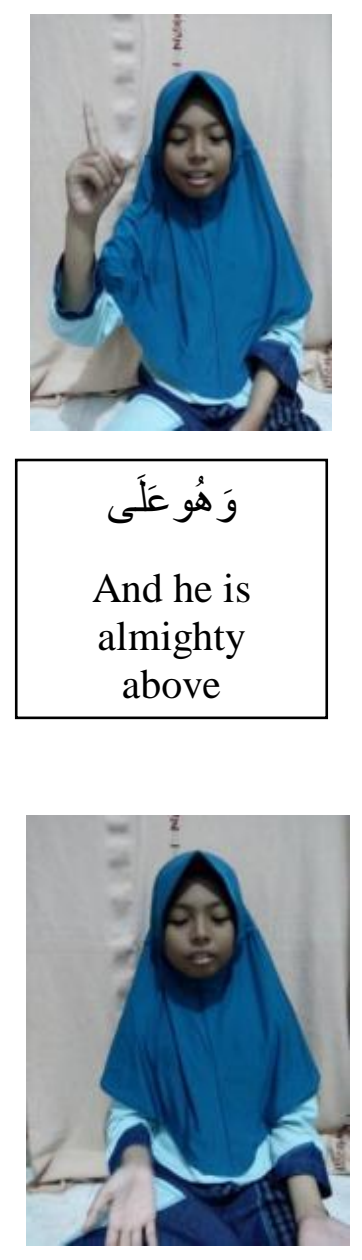

الَّمَوْتَّ
Die

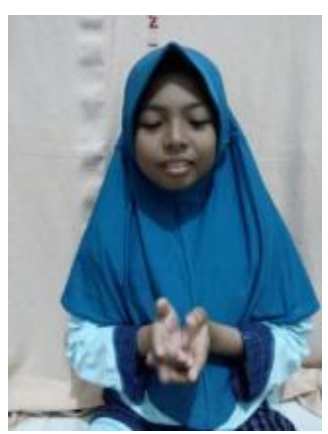

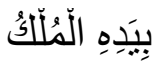

Who controls all kingdoms

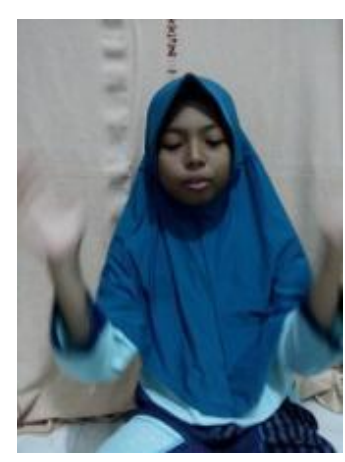

خَلَقَ

Create

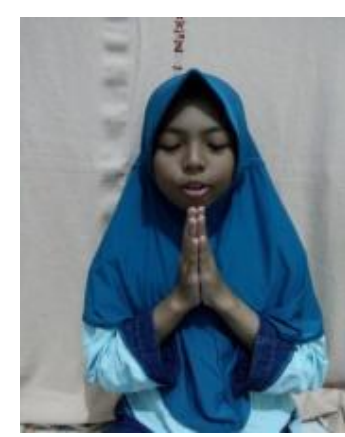

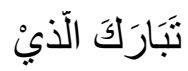

Most holy is Allah

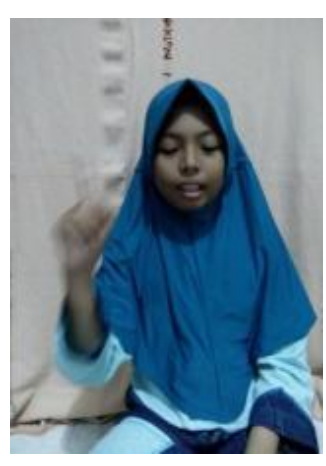

الَّذيْ

Who is he (Allah) 

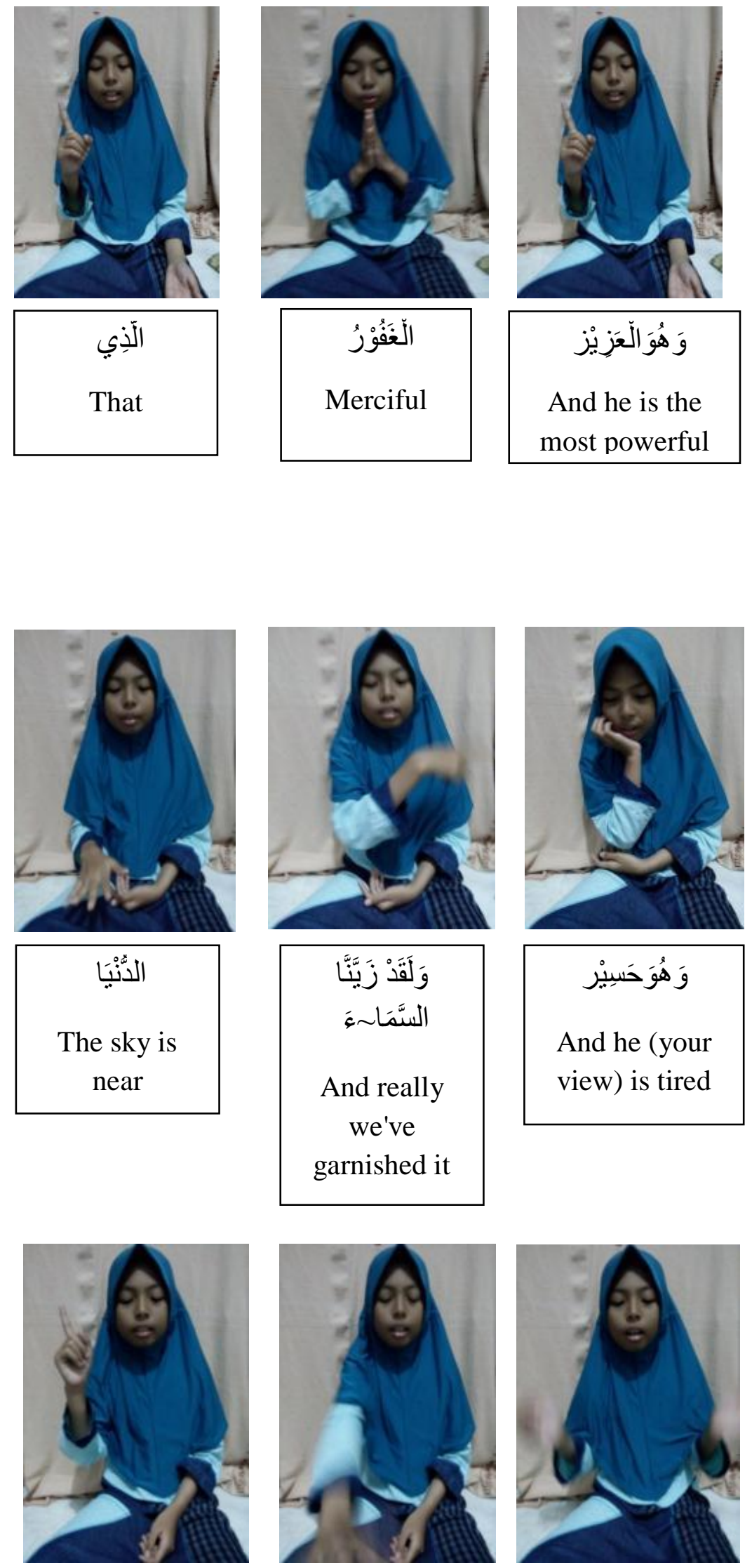

$$
\text { وَاَعْنَدْنَا لَهُْْ }
$$

And we provide them

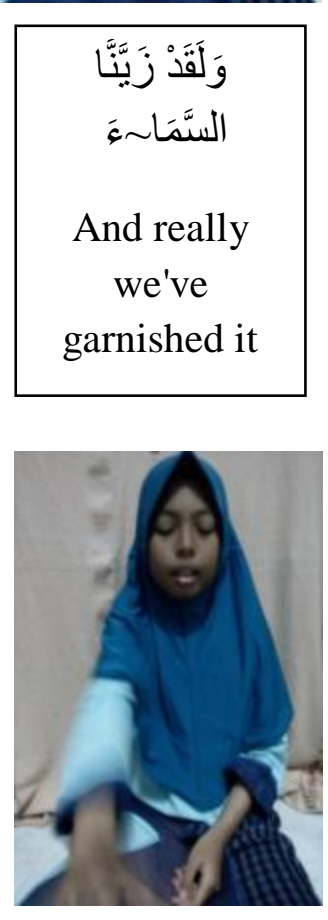

رُجُوْمَا للِلنََّّاطِطِيْنِ

As a throwing device for devil
And he is the
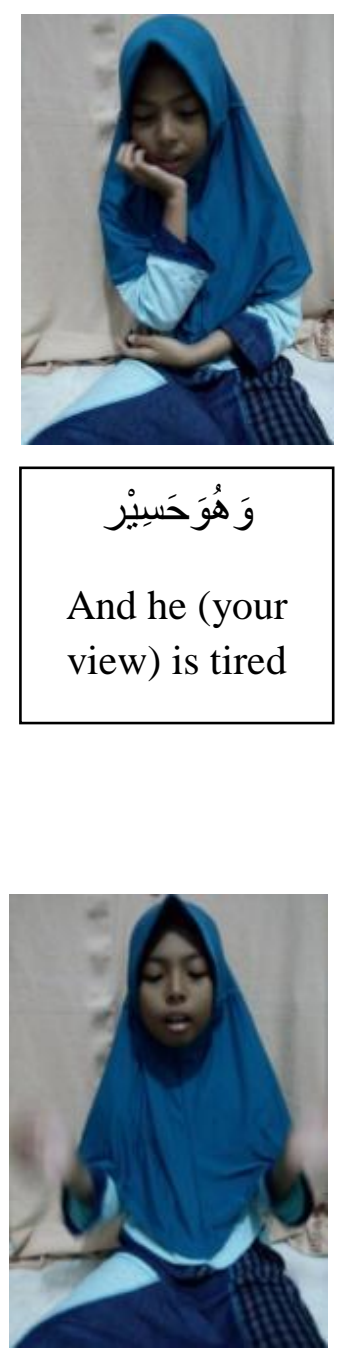

$$
\text { وَهُوَحَبِيْر }
$$

And he (your

view) is tired

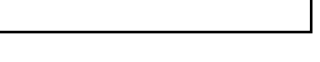
defects

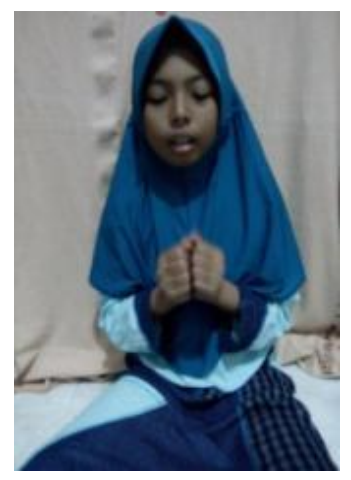

\begin{tabular}{|c|}
\hline 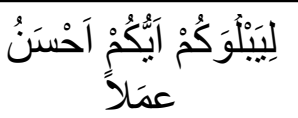 \\
\hline $\begin{array}{c}\text { To test you who } \\
\text { is among you } \\
\text { who has better } \\
\text { charity }\end{array}$ \\
\hline
\end{tabular}

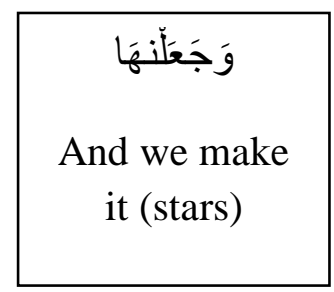

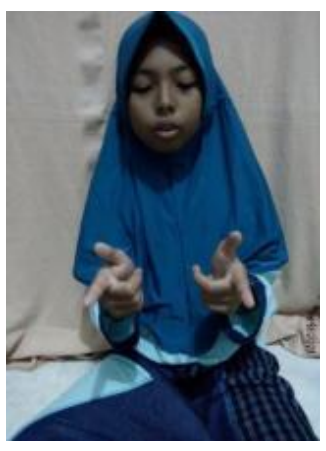

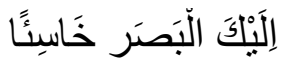

Your gaze will return to you without finding
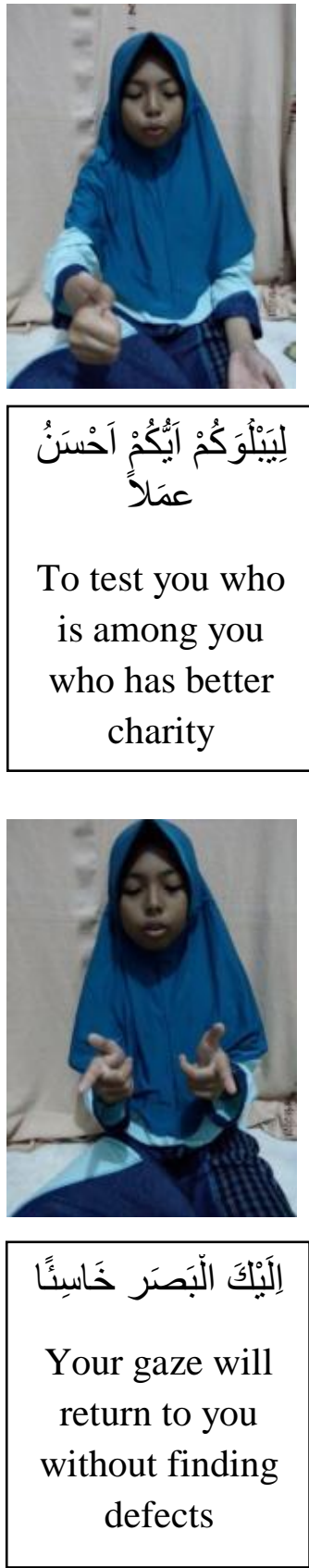

$$
\text { بِمَصَابِيَحَ }
$$

with stars 


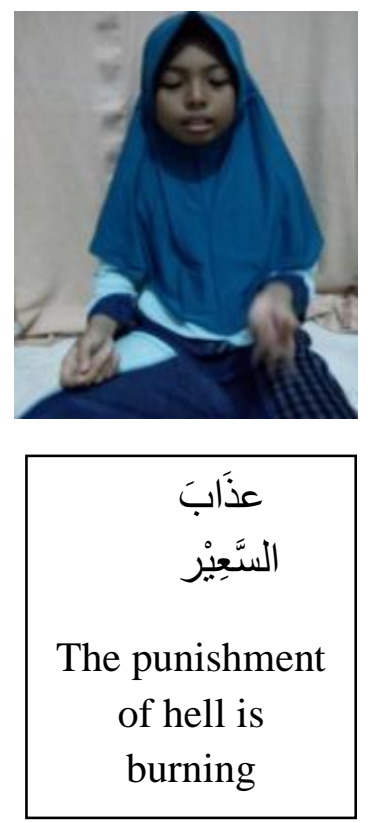

Fifth, Read the verses that have been given by the teacher together according to the movements exemplified by the teacher repeatedly until memorized. Sixth, students advance one by one to practice the movements as exemplified by the teacher. For students who are correct in all movements and verses, a prize will be given. Seventh, after learning is over, all students and the teacher reads the prayer of the Khatmil Qur'an and the regular qoshidah that is read after reading the prayer of khotmil.

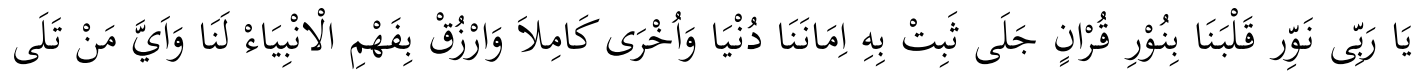

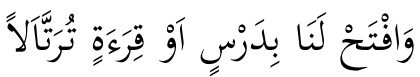

Eighth, Then closed with the final prayer meeting.

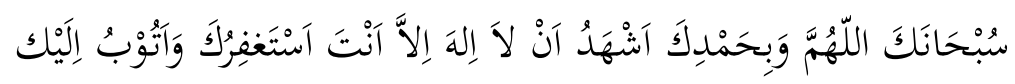

Ninth, the last stage is the teacher closes the learning with greetings. Followed by students shaking hands on the coach.

In Al-quran learning requires a method that must be used by educators so that the learning objectives can be said to be successful. In the program of the Al-Hasyimyah Qur'anic Educational Institution,Nurul jadid, especially elementary / MI level students, can be said to be successful in accordance with (interview with the MINF idz advisorUstadzah Faiqotul Hasanah on 7 December 2018). Al-Qur'an memorization learning process is more than the Gabriel method, although memorizing the verses of the Qur'an is accompanied by movements in each sentence in the verse that is recited. 
According to Imtihana (2016) in his research entitled Impementasi Metode jibril dalam pelaksanaan hafalan Qur'an di SD islam terpadu Ar-Ridho Palembang (The Implementation of Gabriel Method in memorizing the Qur'an in integrated Islamic elementary school Ar-Ridho Palembang) said that there are two stages in the Gabriel method namely tahqiq and tartil.

1. The tahqiq stage is slow and basic Al-Qur'an learning. This stage begins with the introduction of surah and sounds, to words and sentences. This stage deepens the articulation (pronunciation) of a surah correctly in accordance with makhraj and the character of surahs.

2. The tartil stage is learning to read Al-Qur'an with a moderate duration and even fast in accordance with the rhythm of the song. This stage begins with the introduction of a verse or several verses read by the teacher, then imitated by the students repeatedly. Besides the deepening of articulation (pronunciation), in the tartil stage also introduced the practices of tajwid such as: mad reading, waqaf, and ibtida', the law of Nun, Mim, tanwinand so on.

According to Iswandi (2018) in his research entitled Penerapan Metode Jibril dalam Meningkatkan Hafalan Al Qur'an Siswa kelas VII SMP Dr. H. Abdullah Ahmad PGAI Padang (The Application of Gabriel's Method in Improving Al-Qur'an Memorization of Grade VII students of Junior High School Dr. H. Abdullah Ahmad PGAI Padang) stated that learning using the Gabriel method can increase student contributive participation in memorizing the Qur'an and can improve memorization of mastery, as seen from the increasing quantity and quality of student memorization. Increased fluency of students' memorization of memorizing the Al-Qur'an is seen from the increase in scores on each test. cycle I and cycle II.

\section{The Achievement Target of Memorization}

According to Atabik (2014) in his research entitled The Living Qur'an: Potret Budaya Tahfiz Al-Qur'an di Nusantara (The Living Qur'an: Portrait of the Tahfiz Al-Qur'an Culture in the Archipelago) reveals that the student takes about 2 to 4 years to complete memorizing 30 juz in Islamic boarding schools. That is, someone if they want to memorize the Qur'an must be willing to stay at the Islamic boarding school during that time and the minimum age of the student is the junior high school age. According to Suwito (2016) in his research entitled Menghafal cepat selama 40 hari untuk 30 Juz (Studi di Ma'had Tahfidz al-Quran di Dawuhan Purbalingga (40 days Fast Memorization Systemfor 30 Juz (Study in Ma'had Tahfidz al-Quran Dawuhan Purbalingga)) states that the criteria for prospective memorizers of the Qur'an are not in elementary school / Islamic elementary school level. They only accepts junior high school / Islamic junior high school age, because at that age, student's mental memorization and independence ismature. 
In contrast to the research of Atabik and Suwito, in the Nurul Jadid Islamic Boarding School guided 5 people at the elementary school / Islamic elementary school level. The students carry out a deposit once a day after dawn prayers in congregation and institutional activities namely habituation, while the habituation activities are carried out routinely every morning after prayer, in the form of reading juz 30 at least 5 to 6 surahs bin nadzor which is to see manuscripts, followed by boarding activities namely the Development of the Qur'an or the formation of Furudhul Ainiyah. One student has a deposit time of 5 to 7 minutes, and deposit memorization between 2-3 times. Because each student has different abilities. The following is the amount of deposit of elementary school / Islamic elementary school age level students with the results of their achievements:

Table 1. Results of memorization of learners according to surahs and verses

\begin{tabular}{clcc}
\hline No. & \multicolumn{1}{c}{ Name } & Class & \multicolumn{1}{c}{ Result } \\
\hline 1. & Kayla Aulia Amaliyah & VI & Surat Al Mulk 1-30 verses with movements \\
2. & Nayla Aulia Amaniyah & V & Surat Al Mulk verses 1-15 verses with movements \\
3. & Aulia wina Agistina & V & Surah Al mulk verses 1-12 without movement \\
4. & Farah Ghaida Putri Z. & IV & Surah Al mulk verses 1-15 with movements \\
5. & Egha Cassela & IV & Surah Al-Mulk verses 1-7 with movements \\
\hline
\end{tabular}

In table 1, it was found that students at the elementary school/ Islamic elementary school level were able to memorize the highest is one full surah, namely surah Al Mulk verses 1-30 along with movements. The students who achieved the most memorization were the sixth grade students, while the least amount of memorization was fourth grade students. That is, this kind of achievement is obtained because of the level of perseverance and sincerity that they have, not because of the class level. With the achievement of memorization of the Qur'an, it proves that students in elementary school/ Islamic elementary school are also able to memorize the Qur'an.

Just as the research conducted by Ansari (2017) entitled Pelaksanaan Karantina Tahfizh selama 30 Hari untuk Usia SD/MI (The Implementation of 30 days Tahfizh Quarantine for elementary school/ Islamic elementary school). It was stated that students at the elementary school/ Islamic elementary school level were given the opportunity to participate in the tahfidz Al-Quran quarantine. Students who take part in memorizing Al-Qur'an activities do not have to enter Islamic boarding schools, especially for those who are still in school. The Tahfidz AlQur'an quarantine activity is held twice a year during the long school holidays.

According to Ansari \& Barsihanor (2018) in his research entitled Sistem Karantina Tahfidzh 1 Hari untuk Anak Usia SD/MI di Rumah Tahfidzh Al-Haramain Kota Banjarmasin (1 day Tahfidzh Quarantine System for elementary school/ Islamic elementary school in the AlHaramain Tahfidzh House Banjarmasin) proves that students at the elementary school/ Islamic elementary school level are able to memorize the Qur'an by doing one day tahfidz quarantine. 
Tahfidz quarantine 1 day can be an alternative to what potential memorizers can follow to increase and accelerate their memorization quantity. In addition, with a day of gathering with teachers and friends, they can improve participants' social intelligence, because there is a long time between them to interact with each other.

In facilitating memorization of the, students must have strong motivation beside the right method. The desire to memorize the Qur'an does not just come to someone, sometimes the motivation comes from close friends who have memorized the Qur'an first, sometimes also comes from the holding of competitions, or competitions that are held and there arerewards to participate in it. Allah will provide convenience and help for memorizers (Akbar \& Hidayatullah, 2016). Today the word memorizationis no longer a strange thing to hear. Some competitions,events that have been held in order to hone their potential. Memorizing the Qur'an is a blessing for Muslims to understand and remember the contents of it. glorifying the memorizers is one of the safeguards of Allah SWT towards the Qur'an (Mundiri \& Zahra, 2017).

\section{CONCLUSION}

From the results has been described above, it can be concluded that Gabriel method can improve Madrasah Ibtidaiyah students memorization of Quran. It can be seen from the highest achievement of students memorizing is 1 to 2 Surah, while the lowest is 5 to 7 verses and their movements. This difference occurs because of different levels of seriousness which is owned by the learners. The constraints faced in learning activities is its low memory / memories to recall students memorization have achieved and the lack of time for murojaah or repeating it. However, the application of Gabriel method in memorizing the Qur'an is highly recommended, so that the students easier to memorize the Qur'an

\section{REFERENCES}

Akbar, A. \& Hidayatullah, I. (2016). Metode TAhfidz Al-Qur'an di Pondok Pesantren Kabupaten Kampar. Jurnal Usuluddin, 24(1), 91-102.

Akbar, G. (2013). Metode Pembelajaran Alquran melalui Media Online . Indonesian Jurnal on Networking and Security (IJNS), 2(1), 65-68.

Al Maududi, A. A., Mujahidin, E., \& Hafidhuddin, D. (2014). Metode Tahfizh Al-Qur'An bagi Pelajar dan Mahasiswa. Ta'dibuna, 3(1), 1-15.

Ansari, M. I. (2017). Pelaksanaan Karantina Tahfidzh Al-Qur'an 30 Hari untuk Siswa Sekolah Dasar dan Madrasah Ibtidaiyah di Banjarmasin. Jurnal Madrasah Ibtidayah, 2(2), 1-18.

Ansari, M. I., \& Barsihanor. (2018). Sistem Karantina Tahfidzh 1 Hari untuk Anak Usia SD/MI Sistem Karantina Tahfidzh 1 Hari untuk Anak Usia SD/MI. Al-Ibtida: Jurnal Pendidikan Guru MI, 5(2), 205-220. 
Atabik, A. (2014). The Living Qur'an: Potret Budaya Tahfiz Al-Qur'an di Nusantara 8. Jurnal Penelitian, 8(1), 161-178.

Drajat, A. (2017). Ulumul Qur'an. Depok: Kencana.

Fachrudin, Y. (2017). Pembinaan Tahfidz Al-Qur'an di Pesantren Tahfidz Daarul Qur'an Tangerang. Kordinat, 16(2), 331-348.

Herdiansyah, M. Y., \& Afrianto, I. (2013). Pembangunan APlikasi Bantu dalam menghafal AlQur'an Berbasis Mobile. Jurnal ilmiah komputer dan Informatika (KOMPUTA), 2(2), 18.

Imtihana, A. (2016). Impementasi Metode jibril dalam pelaksanaan hafalan Qur'an di SD islam terpadu Ar-Ridho Palembang . Tadrib: Jurnal Pendidikan Agama Islam,, 2(2), 179-197.

Iswandi. (2018). Penerapan Metode Jibril dalam Meningkatkan Hafalan Al Qur'an Siswa Kelas VII SMP Dr. H. Abdullah Ahmad PGAI Padang. Jurnal Pendidikan Islam, 3(2), 37-53.

Jannah, I. M. (2018). Pembelajaran Bahasa Arab dengan Menggunakan Model Cooperative Learning. MODELING, 5(1), 10-24.

Kartiani, B. S. (2015). pengaruh Metode Pembelajaran dan Motivasi Belajar terhadap Hasil Belajar Siswa pada Mata Pelajaran IPS kelas V kabupaten Lombok Barat NTB. Jurnal Pendidikan Dasar, 6(2), 212-221.

Khozim, N. (2010). Strategi pembelajaran Al-Qur'an dalam meningkatkan Kualitas bacaan AlQur'an Santri pondok pesantren Al fatich Surabaya, Tesis. Surabaya : UIN Sunan Ampel.

Majid, A. (2012). Belajar dan Pembelajaran. Bandung: PT. Remaja Rosdakarya.

Martani, W. (2012). Metode stimulasi dan perkembangan emosi anak usia dini. Jurnal Psikologi, $39(1), 112-120$.

Mundiri, A., \& Zahra, I. (2017). Implementasi metode STIFIn dalam meningkatkan kemampuan menghafal Al-Qur'an dirumah Qur'an STIFIn. Jurnal pendidikan Agama Islam, 5(2), 201-223.

Ramli, A. J., K, M., \& Hamzah, M. (2017). Implementation and Development of Qur'an Learning Method. Khalifa, 1(1), 51-76.

Sa'diah, K. (2013). Kualitas Pembelajaran AL-Qur'an dengan metode Tartila di TPQ SAbilun Najah. Jurnal pendidikan Agama Islam, 1(2), 269-286.

Suwito. (2016). Sistem Menghafal Cepat Selama 40 Hari untuk 30 Juz (Studi di Ma'had Tahfidz Al-Quran di Dawuhan Purbalingga). Purwokerto: Laporan penelitian LP2M IAIN Purwokerto. 